\title{
Upper airway irritation and small airways hyperreactivity due to exposure to potassium aluminium tetrafluoride flux: an extended case report
}

\author{
Ulf Hjortsberg, Palle Ørbæk, Måns Arborelius Jr, Jan-Eric Karlsson
}

\begin{abstract}
Objectives-22 workers, exposed to potassium aluminium tetrafluoride used as flux for soldering aluminium, were studied as clinical outpatients for symptoms of irritation of the nose, eye, skin, and airways.

Methods-16 volunteered for spirometry with methacholine provocation test including a test for small airways function by volume of trapped gas (VTG).

Results-Median (range) latency time before respiratory symptoms developed was $6(1-60)$ months. Symptoms of airways irritation diminished in all subjects after flux exposure ended. The $F E V_{1}$ was within the normal range in 16 of 17 subjects before the methacholine provoca-

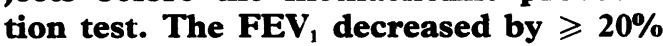
in two out of 16 subjects after the $0.1 \%$ methacholine provocation. Four out of the 17 subjects had a high VTG before methacholine provocation. After inhalation of $0 \cdot 1 \%$ methacholine eight out of 16 subjects $(50 \%)$ had an abnormal increase of VTG indicating hyperreactivity in small airways.

Discussion-Potassium aluminium tetrafluoride flux seems to induce an increase of bronchial reactivity in small airways. A setting of an occupational standard for potassium aluminium tetrafluoride is proposed.
\end{abstract}

(Occup Environ Med 1994;51:706-709)

Keywords: aluminium fluoride, bronchial hyperreactivity, small airways

Flux containing fluorides has been reported as a health hazard when used in soldering of aluminium electric cables. Skin tests indicated that the flux was primarily an irritant and did not cause an allergy. ${ }^{1}$ The flux fume contains free fluorides that are irritating to the skin and the respiratory tract. ${ }^{2}$ Nocturnal bronchospasm has been described among the exposed workers in a large factory in Sweden producing aluminium fluorides. ${ }^{3}$ The bronchial hyperreactivity was considered due to non-specific irritating effects of the exposure to aluminium fluoride.

We studied the respiratory effects of exposure to potassium aluminium tetrafluoride at a small assembly shop. Ten employees were simultaneously exposed to potassium aluminium tetrafluoride applied on aluminium as a water suspension but dried to a fine powder before serving as a soldering flux. Some short or part time employment occurred, but the long term blue collar work force remained stable during the study period. According to technical specifications from the flux producer the flux particles had a median diameter of $1.3 \mu \mathrm{m}$. Sixty per cent of particles were, however, $2-4 \mu \mathrm{m}$. Thus the particles were in the respirable size and likely to deposit in small airways or alveoli. ${ }^{4}$ In the production of aluminium radiators the flux covered metal sheets were assembled under dusty conditions. According to the process operation manual from the flux producer all personnel handling dry flux should wear protective masks, safety goggles, and gloves. Protective measurements, however, were not actively promoted and workers handled the flux without personal protection.

\section{Subjects and methods \\ SUBJECTS}

During a period of 10 years 22 employees from the workshop sought medical attention as outpatients for respiratory, nasal, eye, or skin symptoms at the clinic of Occupational Medicine, Malmö General Hospital. The mean (range) age was 31 (17-63). Fourteen of them were smokers. All 22 were later either relocated away from flux or stopped work.

The methacholine provocation reference group was collected by the Department of Clinical Physiology. It consisted of 21 nonsmoking men aged 41 (24-64) without a personal and family history of asthma or allergy and not exposed to irritating fumes or dusts. The reference value for the volume of trapped gas (VTG) before methacholine provocation was 100 (18) $\mathrm{ml}$ (mean (SD)), and the increase of VTG after inhalation of $0.1 \%$ methacholine was 7 (17) $\mathrm{ml}$ (unpublished). Part of the reference material has been published earlier. ${ }^{5}$ Lung function data were collected from the study and reference groups during the same time period by the same laboratory technicians and equipment.

\section{EXPOSURE}

Between 1985 and 1991 respirable dust and fluoride were measured six times at the work site. Sampling was on membrane filters with personal pumps and precollectors for a whole work day $(8 \mathrm{~h})$. Filters were analysed for dust by a gravimetric method and for fluoride with an ion selective electrode. ${ }^{\circ}$

Between 1985 and 1988 the median 
(range) content of respirable dust was $1 \cdot 1$ $(0.6-2 \cdot 4) \mathrm{mg} / \mathrm{m}^{3}$, and respirable particulate fluoride was $0.3(0.1-0.9) \mathrm{mg} / \mathrm{m}^{3}$. After installation of a central vacuum cleaner in 1988 respirable dust concentration was $0.7(0.4-1 \cdot 3)$ $\mathrm{mg} / \mathrm{m}^{3}$ and respirable particulate fluoride was $0.1(0.03-0.3) \mathrm{mg} / \mathrm{m}^{3}$.

\section{METHODS}

Workers were interviewed for early signs of bronchial hyperreactivity such as nocturnal wheezing, cough and tightness of the chest during exercise. Spirometry was performed with a Bernstein type spirometer. Nitrogen $\left(\mathrm{N}_{2}\right)$ was washed out with a multiple breath technique. ${ }^{7}$ Wash out volume is the exhaled volume during the wash out procedure down to $2 \% \mathrm{~N}_{2}$ in end expiratory air. Volume of trapped gas (VTG) was determined by rebreathing in a closed lung-bag system with five maximal breaths after a deep inhalation of oxygen at the end of the $\mathrm{N}_{2}$ wash out. Nitrogen trapped in the periphery of the lung was thereby mobilised. The VTG was calculated by the following equation: (TLC $\times$ $\mathrm{FN}_{2}$ ER-FRC $\left.\times 0.02\right) / 0.8$, where $\mathrm{FN}_{2} \mathrm{ER}$ is the $\mathrm{N}_{2}$ concentration in the lung-bag system at the end of the rebreathing period, FRC is the functional residual capacity, and TLC is the total lung capacity. As total lung capacity and functional residual capacity are measured with the same procedure the otherwise large variability of these two values does not affect the measurement of VTG, which thus can be determined with high accuracy. ${ }^{7}$ The $\mathrm{N}_{2}$ concentration in exhaled gas was measured by a $\mathrm{N}_{2}$ meter (Ohio 700 nitrogen analyzer, Ohio Medical Products, Houston, USA). Spirometry (including static and dynamic lung volumes) functional residual capacity, and VTG, were measured before and after inhalation provocation with a methacholine aerosol (Pari Inhalior Boy, Pariwerk, Germany) inhaled for two minutes at concentrations of $0.001,0.01$, and $0.1 \%$. Only results after $0 \cdot 1 \%$ methacholine are presented as being found to have the best discriminative power in a previous study. ${ }^{5}$
Total serum IgE concentration was measured by the PRIST test (Pharmacia Diagnostics AB, Uppsala).

\section{Results}

SYMPTOMS

Median (range) latency time for the development of respiratory symptoms was 6 (1-60) months. Of the 22 symptomatic subjects 21 reported a cough or chest tightness after exposure to the flux. Nine of these subjects also reported symptoms of rhinitis. Five of them had eye irritation and four reported skin itching (table 1). All workers exposed to flux reported a slow improvement of symptoms during sick relief and after the end of flux exposure. Five of the subjects reported asthma among close relatives.

Median (range) blood eosinophils count was $22210^{6}(46-642) / 1$ and total serum IgE concentration $19(5-1000) \mathrm{kU} / 1$. Three subjects had high (> $100 \mathrm{kU} / \mathrm{l})$ total serum IgE concentrations of $120 \mathrm{kU} / \mathrm{l}, 120 \mathrm{kU} / 1$ and $1000 \mathrm{kU} / 1$ (table 2).

\section{LUNG FUNCTION TESTS}

The median (range) $\mathrm{FEV}_{1}$, as a percentage of predicted, was 95 (79-124) before the provocation. After the $0 \cdot 1 \%$ methacholine provocation the mean $\mathrm{FEV}_{1}$ decrease was $6 \%$. Two out of 16 subjects examined $(13 \%)$ had $a \geqslant$ $20 \%$ fall of $\mathrm{FEV}_{1}$ (table 2). Four out of 17 subjects examined (24\%) had an increased VTG before the methacholine provocation test. After provocation with $0.1 \%$ methacholine eight out of 16 examined subjects $(50 \%)$ had an abnormal increase of VTG compared with the reference values of our laboratory. No correlation was found between blood IgE or eosinophils and the increase in VTG with $0 \cdot 1 \%$ methacholine.

\section{Discussion}

Our main finding was that symptoms of respiratory irritation and small airway hyperreactivity were common among the workers

Table 1 Family history of atopy, age, latency time after flux exposure, eye, nose, airways, and skin symptoms

\begin{tabular}{|c|c|c|c|c|c|c|c|}
\hline Patient & $\begin{array}{l}\text { Family history } \\
\text { of atopy }\end{array}$ & Age (y) & $\begin{array}{l}\text { Latency before } \\
\text { onset (months) }\end{array}$ & Conjunctivitis & Rhinitis & $\begin{array}{l}\text { Cough or } \\
\text { chest tightness }\end{array}$ & Skin itching \\
\hline 1 & - & 24 & 5 & - & + & + & - \\
\hline 2 & - & 21 & 4 & - & - & + & - \\
\hline 3 & + & 22 & 1 & - & - & + & + \\
\hline 4 & - & 29 & 2 & - & - & + & - \\
\hline 5 & + & 21 & 24 & + & + & + & + \\
\hline 6 & - & 40 & 1 & - & - & + & - \\
\hline 7 & - & 20 & 1 & - & + & + & - \\
\hline 8 & + & 37 & 20 & + & + & + & - \\
\hline 9 & + & 17 & 2 & - & - & + & - \\
\hline 10 & - & 19 & 5 & - & - & + & - \\
\hline 11 & - & 19 & 1 & - & - & + & - \\
\hline 12 & - & 32 & i & - & - & + & - \\
\hline 13 & - & 22 & 3 & - & - & + & - \\
\hline 14 & - & 43 & 6 & + & + & - & - \\
\hline 15 & - & 32 & 24 & - & + & + & - \\
\hline 16 & - & 48 & 36 & - & - & + & - \\
\hline 17 & - & 30 & 60 & - & - & + & - \\
\hline 18 & + & 22 & 36 & - & - & + & - \\
\hline 19 & - & 63 & 36 & - & - & + & - \\
\hline 20 & - & 31 & 16 & - & + & + & - \\
\hline 21 & - & 37 & 14 & + & + & + & + \\
\hline 22 & - & 38 & 13 & + & + & + & + \\
\hline
\end{tabular}


Table 2 Measurement before and after provocation

\begin{tabular}{|c|c|c|c|c|c|c|c|}
\hline Patients & Smoking & Eosinophils & $\begin{array}{l}\text { Total } \\
\text { serum } \\
\text { IgE }\end{array}$ & $\begin{array}{l}F E V \text {, as \% } \\
\text { predicted before } \\
\text { provocation }\end{array}$ & $\begin{array}{l}F E V, \text { as } \% \\
\text { predicted after } \\
0 \cdot 1 \% \text { methacholine }\end{array}$ & $\begin{array}{l}V T G \text { before } \\
\text { provocation }\end{array}$ & $\begin{array}{l}V T G \text { after } \\
0.1 \% \text { methacholine }\end{array}$ \\
\hline 1 & yes & 419 & 5 & 116 & 113 & $166^{\star}$ & $290^{\star}$ \\
\hline 2 & yes & 255 & 12 & 93 & 90 & 74 & 321 * \\
\hline 3 & no & 46 & 8 & 91 & 85 & 94 & $325^{\star}$ \\
\hline 4 & yes & - & - & 90 & 86 & 106 & $299^{\star}$ \\
\hline 5 & yes & 425 & 45 & 113 & 115 & 75 & 122 \\
\hline 6 & no & 85 & 20 & 108 & 114 & 61 & 86 \\
\hline 7 & no & 170 & 22 & 92 & 91 & 72 & 75 \\
\hline 8 & no & 255 & 19 & 97 & 78 & 102 & $298^{\star}$ \\
\hline 9 & yes & 440 & 18 & 90 & 88 & 93 & 74 \\
\hline 10 & yes & 620 & 1000 & 94 & 85 & 122 & $474^{\star}$ \\
\hline 11 & no & 80 & 28 & 79 & 71 & $139^{\star}$ & $178^{\star}$ \\
\hline 12 & no & 380 & 120 & 101 & 93 & $175^{\star}$ & 166 \\
\hline 13 & yes & 642 & 5 & - & - & - & - \\
\hline 14 & yes & 250 & 55 & - & - & - & - \\
\hline 15 & yes & 194 & 16 & - & - & - & - \\
\hline 16 & no & 151 & 85 & 124 & 115 & 52 & 59 \\
\hline 17 & yes & - & 5 & - & - & - & - \\
\hline 18 & yes & 52 & 190 & 95 & - & 72 & - \\
\hline 19 & yes & 157 & 5 & - & - & - & - \\
\hline 20 & no & 180 & - & 95 & 68 & 121 & $604^{\star}$ \\
\hline 21 & yes & 50 & 5 & 106 & 104 & 132 & 113 \\
\hline 22 & yes & 320 & 5 & 119 & 117 & $198^{\star}$ & 188 \\
\hline
\end{tabular}

ॠTG>2 SD

Reference range for eosinophils is $10-60010 \% 1$. Reference level for IgE is < $100 \mathrm{kU} / \mathrm{l}$. Reference value for VTG before provocation is mean (SD) of $100(18) \mathrm{ml}$. Increase of VTG after $0 \cdot 1 \%$ methacholine is a mean (SD) of 7 (17) $\mathrm{ml}$.

exposed to potassium aluminium tetrafluoride flux. Exposure to flux seems to induce and exacerbate a pre-existing bronchial hyperreactivity in the small airways of a substantial proportion of exposed subjects. Respiratory symptoms decreased or disappeared after the end of the flux exposure. There were no preemployment methacholine provocation tests available. Tobacco smoking might contribute to bronchial hyperreactivity in subjects with high cumulative tobacco exposure ${ }^{8}$ The association, however, between flux exposure and onset of subjective symptoms of airways obstruction favours potassium aluminium tetrafluoride being the main causative factor. In animal experiments aluminium fluoride has been found to be a potent contractile agent of airways smooth muscle. ${ }^{9}$ The particle size of the flux favours settlement in small airways and alveoli. Our findings are in accordance with reported effects of exposure in potroom workers. ${ }^{10}$

Symptoms of asthma or bronchial hyperreactivity in the absence of an increased prevalence of atopy has been reported among potroom workers. ${ }^{11}$ The bronchial hyperreactivity seems to increase slowly and might eventually become permanent. Exposed workers may not have breathing difficulties at a stage when hyperreactivity in small airways can be detected by VTG combined with methacholine inhalation. Symptoms of obstructive airways might be absent early in the asthmatic disease. Dyspnea is usually uncommon before a decrease in $\mathrm{FEV}_{1}$ is present.

We have found that the increases in the VTG after $0.1 \%$ methacholine range from several tenths up to $\geqslant 1000 \mathrm{ml}$ in overt asthma. In a previous study we found that after $0.1 \%$ methacholine provocation an increase of VTG of $>500 \mathrm{ml}$ indicates severe small airways hyperreactivity as in small airways closure with ventilatory inhomogeneity. The VTG correlates with other tests of small airways function such as maximum expiratory flow at $50 \%$ and $75 \%$ of vital capacity $\left(\mathrm{MEF}_{50}, \mathrm{MEF}_{75}\right) .^{12}$ The VTG is more sensitive and specific than $\mathrm{MEF}_{75}$ for the diagnosis of exercise induced bronchospasm in children. ${ }^{13}$

Potroom workers show a moderate decrease of $\mathrm{FEV}_{1}$ and an increase in residual volume, suggesting a mainly peripheral obstruction. ${ }^{14}$ No effect of bronchial reactivity, as examined by $\mathrm{FEV}_{1}$, was found in potroom workers at exposures of $1.77 \mathrm{mg} / \mathrm{m}^{3}$ of total dust or $0.31 \mathrm{mg} / \mathrm{m}^{3}$ of total (gaseous and particulate) fluoride. ${ }^{14}$ When air concentration of fluoride is higher, however, bronchial hyperreactivity in large airways occurs. ${ }^{15}$ Fluoride exposures, and particle size, thus seem important as to whether bronchial hyperreactivity is manifest in small or large airways. No asthma occurred at exposure to an aluminium tetrafluoride dust of $0 \cdot 1$ $\mathrm{mg} / \mathrm{m}^{3} .^{3}$ In our study about $50 \%$ of exposed subjects developed signs of small airways hyperreactivity and respiratory symptoms at dust levels below current Swedish standards for fluoride $\left(2 \mathrm{mg} / \mathrm{m}^{3}\right)$.

We suggest setting a standard at $0.1 \mathrm{mg} / \mathrm{m}^{3}$ for potassium aluminium tetrafluoride in respirable dust, measured as particulate fluoride. Health checkups some months after the start of exposure are recommended among employees exposed to potassium aluminium tetrafluoride dust to detect any signs of early onset of hyperreactivity in large bronchial or small airways. At checkups a methacholine provocation test with measurement of FEV and VTG is recommended.

We thank occupational hygienist Dr Gun Nise (Med Sci) for performing part of the flux sampling at the work place.

McCann JK. Health hazard from flux used in joining alu minium electricity cables. Ann Occup Hyg 1964;7:261-8. Sterling GM. Asthma due to aluminium soldering flux. Thorax 1967;22:533-7.

3 Simonsson BG, Sjöberg A, Rolf C, Haeger-Aronsen B. Acute and long-term airway hyperreactivity in aluminium-salt exposed workers with nocturnal asthma. Eur $\mathcal{F}$ Respir Dis 1985;66:105-18. 
4 Dudek R, MacKellar D. Study 420-1923: one hour acute flux dust inhalation toxicity study in rats, a report of April 12, 1985. Decatur, Il: American Biogenics Corporation, 1985 .

5 Hjortsberg U, Arborelius M Jr, Ørbæk P. Small airway dysfunction among non smoking isocyanate exposed workers. Br f Ind Med 1987;44:824-8.

6 Health and Safety Executive. Methods for the determination of toxic substances in the air. Booklet No 19. Hydrogen fluoride and other inorganic fluorides. London: HMSO, 1970.

7 Christensson P, Arborelius M Jr, Kautto R. Volume of trapped gas in lungs of healthy humans. I Appl Physiol 1981;51:172-5.

8 O'Connor GT, Sparrow D, Weiss ST. The role of allergy and nonspecific airway hyperresponsiveness in the pathogenesis of chronic obstructive pulmonary disease. pathogenesis of chronic obstructive put

9 Leurs R, Bast A, Timmerman H. Fluoride as a contractile agent of guinea pig airway smooth muscle. Gen Pharmacol 1991;22:631-6.

10 Søyseth V, Kongerud J. Prevalence of respiratory disorders among aluminium potroom workers in relation to expo- sure to fluoride. $\mathrm{Br} \mathcal{F}$ Ind Med 1992;49:125-30.

11 Saric M, Godnic-Cvar J, Gomzi M, Stilinovic L. The role of atopy in potroom workers asthma. Am $\mathcal{F}$ Ind Med $1986 ; 9 \cdot 239-42$.

12 Dahlquist $M$, Alexandersson $R$, Nielsen J, Hedenstjerna G. Single and multiple breath nitrogen wash outclosing volume and volume of trapped gas for detection of early airway obstruction. Clin Physiol 1989;9: 389-98.

13 Arborelius M Jr, Svenonius E, Kautto R. Volume of trapped gas and maximum flow at $25 \%$ of vital capacity in exercise-induced asthma. In Sadoul $P$, Milic-Emili J, Simonsson BG, Clark TJH, eds: Small airways in health and disease, proceedings of a symposium, Copenhagen 29thand disease, proceedings of a symposium, Copenhagen 29th

14 Larsson $K$, Eklund A Arns R, Lowgta $H$, Nyström J, Sundström $G$, Tornling $G$. Lung function and bronchial reactivity in aluminium potroom workers. Scand $f$ Work reactivity in aluminium potroom

15 de Vries $K$, Löwenberg A, Coster van Voorhout HEV, Ebels JH. Langzeitbeobachtungen bei Fluorwasserstoffexposition. Pneumologie 1974;150:149-54.

\section{Vancouver style}

All manuscripts submitted to Occup Environ Med should conform to the uniform requirements for manuscripts submitted to biomedical journals (known as the Vancouver style.)

Occup Environ Med, together with many other international biomedical journals, has agreed to accept articles prepared in accordance with the Vancouver style. The style (described in full in the BMF, 24 February 1979 , p 532) is intended to standardise requirements for authors.

References should be numbered consecutively in the order in which they are first mentioned in the text by Arabic numerals above the line on each occasion the reference is cited (Manson ${ }^{1}$ confirmed other reports $^{2-5} \ldots$. .). In future references to papers submitted to Occup Environ Med should include: the names of all authors if there are seven or less or, if there are more, the first six followed by $e t$ al; the title of journal articles or book chapters; the titles of journals abbreviated according to the style of Index Medicus; and the first and final page numbers of the article or chapter. Titles not in Index Medicus should be given in full.

Examples of common forms of references are:

1 International Steering Committee of Medical Editors, Uniform requirements for manuscripts submitted to biomedical journals. Br Med F 1979;1:532-5.

2 Soter NA, Wasserman SI, Austen KF. Cold urticaria release into the circulation of histamine and eosinophil chemotactic factor of anaphylaxis during cold challenge. $N$ Engl $\mathcal{f}$ Med 1976;294:687-90.

3 Weinstein $L$ Swart MN. Pathogenic properties of invading micro-organisms. In: Sodeman WA Jr, Sodeman WA eds Pathologic physiology mechans of disease. Philadelphia: W B Saunders, 1974:457-72. 